\title{
Flipped Classroom Method for the Teacher Training for Secondary Education: A Case Study in the University of Granada, Spain
}

\author{
https://doi.org/10.3991/ijet.v14i11.9853 \\ Francisco-Javier Hinojo-Lucena ${ }^{(凶)}$, Inmaculada Aznar-Díaz, \\ María-Pilar Cáceres-Reche, José-María Romero-Rodríguez \\ University of Granada, Granada, Spain \\ fhinojo@ugr.es
}

\begin{abstract}
Flipped Classroom methodology has strongly introduced in the classrooms of different educational levels, but above all in the University. This methodology could be defined as the reversal of roles in the classroom, where the student acquires theoretical knowledge outside of the classroom and becomes a space for resolving doubts and cooperative work. Thus, this paper analyzes the experience carried out at the University of Granada with students of the Master's Degree in Secondary School Training where Flipped Classroom methodology has been applied. The research methodology used is quantitative, so that an ad hoc questionnaire on a Likert scale was used to obtain the data. Among the obtained results, it is observed that the students perceive an improvement in their academic performance and the improvement of the different personal and social skills. Finally, it can be concluded that this kind of experiences where the Flipped Classroom methodology is applied favors the development of skills depending of subject taught and the field of knowledge.
\end{abstract}

Keywords-Flipped Classroom, Higher Education, ICT, Teaching Methodology.

\section{Introduction}

In recent years, the Flipped Classroom methodology is being implemented in the classrooms of different educational levels, which it is defined as the flipped of roles in the classroom, where the student acquires the theoretical knowledge outside and the classroom becomes a propitious space for resolving doubts and cooperative work [1, 2]. Therefore, the student previously works the contents outside the school context from the use of digital tools to develop them later in the classroom.

On the other hand, the origin of this methodology born in the concern of two teachers to oppose school absenteeism, likewise they began to record their presentations with audio to offer as support material to students [3]. From this experience they realized that this teaching method favored the development of certain benefits, among them those highlighted by the pioneers Bergmann and Sams [4] and collected in Gértrudix and Rivas [5], Zainuddin and Hajar [6] and Rincón [7]: development of a collaborative learning environment, dynamizes the role of students, actualization of 
the teaching role, allows autonomous learning, fosters student skills and facilitates the deployment of interactive participatory tasks. These advantages associated with the Flipped Classroom methodology can be verify in different investigations carried out in which its acquisition becomes evident $[8,9,10,11,12,13]$.

In keeping with Miragall and García-Soriano [14] among the features of Flipped Classroom we find:

- The content is previously worked

- Students acquire an active role in their learning. This methodology is based on in constructivism and in the social learning theory [15]

- Significant learning occurs

- The teachers acts as a guide and is aware of the students' knowledge

Therefore, taking into account these considerations there is a change of roles in relation to the traditional master class model, in which students are merely a receiver of contents and the teacher is limited to transmitting information. On the other hand, the Flipped Classroom change this situation around and the students acquire a leading role in their learning, while the teachers act as a guide facilitating the learning content. So that in its implementation the teacher selects a series of videos that can be coupled with questions that the students consult outside the classroom, with the possibility of writing down the individual doubts to take them later to class. In the same way, previously working on the subject, it is possible to form cooperative groups in class to reinforce the content among equals.

Finally, it should be noted that the relevance and effectiveness of this methodology depends largely on the type of content of the subject taught, so Barao and Palau [16] emphasize that in the mathematics subject it is complicated to implement the Flipped Classroom in all teaching units. Consequently, it is the teacher's task to know how to apply this methodology to combine it with face-to-face and extensive explanations in those contents that present difficulties in the autonomous learning of the students [17].

\section{Methodology}

In this paper, a descriptive quantitative methodology has been used [18], with the purpose of knowing the experience on the implementation of the Flipped Classroom methodology. The sample was composed by two groups of students of the Master's Degree in Compulsory Secondary Education and Baccalaureate, Vocational Training and Language Teaching, specialty of Mathematics and Geography and History of the University of Granada, to which the Flipped Classroom methodology has been applied in the development of class sessions on the subject of "Society, Family and Education" during the 2017-2018 academic year.

Thus, it has been used a questionnaire, prepared ad hoc, based on a Likert scale of 4 levels as a data collection instrument: Items 1-8 $(1=$ Totally disagree, $2=$ Disagree, $3=$ Agree, $4=$ Totally agree $)$ and item $9(1=$ Very unsatisfactory, $2=$ Unsatisfactory, $3=$ Satisfactory, $4=$ Very satisfactory). Although the original questionnaire consists of 26 items, for this paper we have selected the 9 items corresponding to the devel- 
opment of skills and satisfaction of the experience developed, where it is revealed the degree of student accordance with this methodology (table 1). In relation to the reliability of the questionnaire the analysing of the 9 items show a reliability index of .91 (Cronbach's alpha coefficient).

The sample was composed of 82 students in total, 42 from the specialty of Mathematics and 40 from Geography and History. The data were analysed with the statistical program SPSS in its version 25, which has allowed to perform various statisticaldescriptive operations to obtain the percentage of response in each item according to the Likert scale.

Table 1. Questionnaire items on the development of skills and student satisfaction with the Flipped Classroom experience

\begin{tabular}{|l|l|}
\hline Q1 & Academic performance \\
\hline Q2 & Development of creativity and innovative ideas in teaching \\
\hline Q3 & Development of metacognitive skills \\
\hline Q4 & Development of social and personal skills \\
\hline Q5 & Greater knowledge and learning through teamwork \\
\hline Q6 & Increase of my interest and personal motivation towards the subject \\
\hline Q7 & Acquisition of a comprehensive knowledge, practical, transferable to other subjects and to reality \\
\hline Q8 & $\begin{array}{l}\text { I prefer to work through active methodologies such as Flipped Classroom as opposed to traditional } \\
\text { teaching methods (master lesson) }\end{array}$ \\
\hline Q9 & The global assessment of my learning experience with this teaching methodology \\
\hline
\end{tabular}

\section{Results}

In relation to the characteristics of the sample $(n=82)$, if we look at the gender it has been composed of 55\% (male) and $45 \%$ (female). On the other hand, the age of the participants is diverse: among the $19-23$ years is $32 \%$ of the students, $24-28$ years $(44 \%)$, being the age where the largest population is concentrated, 29-33 years (13\%), $34-38$ years $(5 \%)$ and more than 39 years $(6 \%)$.

Regarding the answers to the questionnaire, each item obtains its own scores that, although they vary among them, are similar percentages in the different values. Thus, in the question about "Academic performance" (Q1), the answers have been totally disagree $(4.9 \%)$, disagree $(26.8 \%)$, agree $(61 \%)$ and totally agree $(7.3 \%)$. With measures of central tendency referring to the mean: 2.71 , media: 3 , mode: 3 and a standard deviation of .67 points. In the "Development of creativity and innovative ideas in teaching" (Q2), totally disagree $(4.9 \%)$, disagree $(15.9 \%)$, agree $(62.2 \%)$ and totally agree (17.1\%). Mean: 2.91, media: 3, mode: 3 and standard deviation: .72 points. In "Development of metacognitive skills" (Q3), totally disagree (6.1\%), disagree $(25.6 \%)$, agree $(52.4 \%)$ and totally agree (15.9\%). Mean: 2.78 , median: 3 , mode: 3 and standard deviation: .78 points. In "Development of social and personal skills" (Q4), totally disagree $(4.9 \%)$, disagree $(13.4 \%)$, agree $(64.6 \%)$ and totally agree (17.1\%). Mean: 2.94 , median: 3 , mode: 3 and standard deviation: .70 points. In relation to "Greater knowledge and learning through teamwork" (Q5), totally disagree $(2.4 \%)$, disagree $(25.6 \%)$, agree $(54.9 \%)$ and totally agree $(17.1 \%)$. Mean: 2.87 , me- 
dian: 3, mode: 3 and standard deviation: .71 points. In "Increase of my interest and personal motivation towards the subject" (Q6), totally disagree (6.1\%), disagree $(23.2 \%)$, agree $(59.8 \%)$ and totally agree (11\%). Mean: 2.76 , median: 3 , mode: 3 and standard deviation: .73 points. Following with the data obtained, in the question "Acquisition of a comprehensive knowledge, practical, transferable to other subjects and to reality" (Q7), totally disagree $(2.4 \%)$, disagree $(17.1 \%)$, agree $(64.6 \%)$ and totally agree (15.9\%). Mean: 2.94, median: 3, mode: 3 and standard deviation: 65 points. And finally, in "I prefer to work through active methodologies such as Flipped Classroom as opposed to traditional teaching methods (master lesson)" (Q8), totally disagree $(3 \%)$, disagree $(20.7 \%)$, agree $(51.2 \%)$ and totally agree $(24.4 \%)$. Mean: 2.96 , median: 3, mode: 3 and standard deviation: .77 points.

Finally, in the final question about "The global assessment of my learning experience with this teaching methodology" (Q9), the results have been positive $(81.7 \%)$ (figure 1). With a mean: 2.99 , media: 3 , mode: 3 and standard deviation of 67 points.

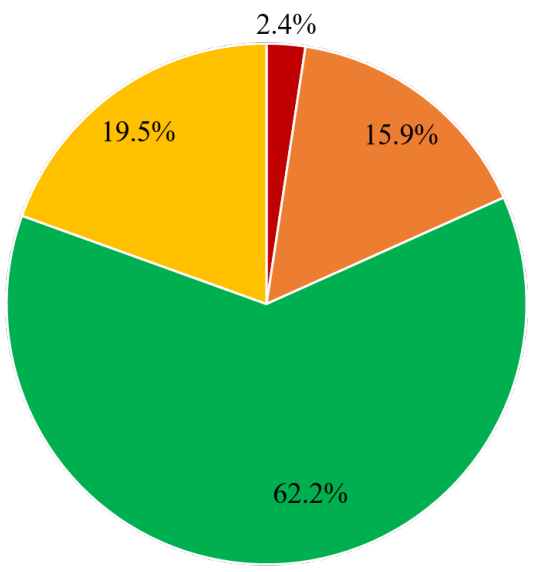

-Very unsatisfactory $\quad$ Unsatisfactory $\quad$ Satisfactory $\square$ Very satisfactory

Fig. 1. Percentage of student satisfaction with respect to the Flipped Classroom experience

\section{Discussion and Conclusion}

In relation to the answers of the participants, these are homogeneous in all the items as it reflects the low standard deviation, less than .8 points in all of them. Therefore, according to the median and mode, the answers are accumulated in the value 3 (agree), thus highlighting a positive perception in the application and development of the Flipped Classroom methodology. Thus, the participants consider the improvement in academic performance in the same line as the pioneers Bergmann and Sams [4], which highlight the Flipped Classroom as a method for improving learning. 
Likewise, the fact of giving the students autonomy in carrying out the tasks [14] affects the development of creativity, as confirmed in this experience. Regarding the development of personal and communication skills, these are enhanced by teamwork that favours the Flipped Classroom $[8,12,13]$, in the same way that the percentage of student agreement is $81.7 \%$ (social and personal skills) and $72 \%$ (teamwork).

On the other hand, the fact that the Flipped Classroom methodology promotes the active role of students and the flipped of roles, displacing the teacher to a secondary level, incurs the student's intrinsic motivation (70.8\% of agree), as González, Jeong, Cañada and Gallego [15] indicates. In this sense, the acquisition of knowledge is amplified due to the combination of the motivational and significant learning components developed by the student [10] and is perceived in this experience (80.5\%).

Finally, the general assessment of the students is satisfactory with an agreement percentage of $81.7 \%$, where the students' preference is shown for working with an active methodology such as the Flipped Classroom versus the master class. In short, the students' general perception of the experience and skills developed with the Flipped Classroom, both in this paper and in those previously done $[9,11]$, make this methodology a powerful resource for improving the teaching-learning

In consideration, with the development of this work on the implementation of the Flipped Classroom methodology has responded to the objective raised about knowing the experience of the Masters' degree students on this methodology. Likewise, the different items raised provide relevant data of the Flipped Classrooms' virtualities to enhance diverse personal, academic and social skills. So that not only the academic dimension of the student is affected, but the experienced skills are transferred transverse to other facets of life. However, it is important to highlight the importance of working with future teachers on innovative methodologies such as the Flipped Classroom, since experiences of this type empower and provide teachers with resources so that in the future they can be implemented in their classrooms. However, it is of vital importance to know the didactic content of the subject, since as indicated by Barao and Palau [16] some disciplines require a more deliberate and directed treatment, as in this case the specialties of Mathematics and Geography and History. Therefore, in these subjects it is necessary to combine the Flipped Classroom with other resources that help to understand the key concepts and favour the autonomous learning of the student.

In summary, the Information and Communication Technologies (ICT) converge in teaching methodologies that place the focus of attention on the student and foster their autonomy in learning. The Flipped Classroom methodology is found in this line, incurring multiple benefits for teaching, such as those cited in the previous studies of other authors and those collected in this experience.

\section{Acknowledgement}

This paper is part of the teaching innovation and good practices project of the FIDO plan of the University of Granada (Code 17-12), having received public funding for its development. 


\section{References}

[1] Castilla, G., Alriols, J., Romana, M., \& Escribano, J.J. (2015). Resultados del estudio experimental de flipped learning en el ámbito de la enseñanza de matemáticas en ingeniería. In XII Jornadas Internacionales de Innovación Universitaria, Educar para transformar: aprendizaje experiencial. Madrid, Spain: Europe University of Madrid. pp. 774-782 https://doi.org/10.12795/jdu.2018.i01.43

[2] Yang, L., Sun, T., \& Liu, Y. (2017). A Bibliometric Investigation of Flipped Classroom Research during 2000-2015. International Journal of Emerging Technologies in Learning, 12(6): 178-186. DOI:10.3991/ijet.v12i06.7095 https://doi.org/10.3991/ijet.v12i06.7095

[3] Sánchez, M.M., Solano, I.M., \& González, V. (2016). FLIPPED-TIC: A Flipped Classroom experience with preservice teachers. RELATEC. Revista Latinoamericana de Tecnología Educativa, 15(3): 69-81. DOI:10.17398/1695-288X.15.3.69

[4] Bergmann, J., \& Sams, A. (2012). Flip your classroom: Reach every student in every class every day. Eugene, OR: International Society for Technology in Education. https://doi.org/10.1177/073989131401100120

[5] Gértrudix, F., \& Rivas, B. (2015). Production and instructional design of teaching-music videos. An open learning experience and flipped classroom. Educatio Siglo XXI, 33(1): 277-294. DOI:10.6018/j/222601 https://doi.org/10.6018/j/222601

[6] Zainuddin, Z., \& Hajar, S. (2016). Flipped Classroom Research and Trends from Different Fields of Study. International Review of Research in Open and Distributed Learning, 17(3): 313-340. https://doi.org/10.19173/irrodl.v17i3.2274

[7] Rincón, A.G. (2016). Opiniones de los docentes en formación inicial acerca del aprendizaje inverso. In R. Roig-Vila (ed.), Tecnología, innovación e investigación en los procesos de enseñanza-aprendizaje. Barcelona, Spain: Octaedro. pp. 2944-2951. https://doi.org/10.6018/riite/2018/342681

[8] Huesca, G. (2016). Comparative analysis of learning gains in three flipped classroom methodologies versus traditional teaching. Revista de Investigación Educativa de la Escuela de Graduados en Educación, 7(13): 26-31.

[9] Opazo, A.R., Acuña, J.M., \& Rojas, M.P. (2016). Flipped Classroom Assessment Method: first experience. Innoeduca, 2(2): 90-99. doi:10.20548/innoeduca.2016.v2i2.1966 https://doi.org/10.20548/innoeduca.2016.v2i2.2030

[10] Díaz, E., Martín, M.L., \& Sánchez, J.M. (2017). The impact of Flipped Classroom on the motivation and learning of students in Operations Management. Working Papers on Operations Management, 8: 15-18. https://doi.org/10.4995/wpom.v8i0.7091

[11] Sacristán, M., Martín, D., Navarro, E., \& Tourón, J. (2017). Flipped classroom and mathematics didactics in online education of Early Childhood Teachers. Revista Electrónica Interuniversitaria de Formación del Profesorado, 20(3): 1-14. DOI:10.6018/reifop.20.1.292551 https://doi.org/10.6018/reifop.20.3.292551

[12] Mingorance, A.C., Trujillo, J.M., Cáceres, P., \& Torres, C. (2017). Improvement of academic performance through the flipped classroom methodology centered in the active learning of the university student of education sciences. Journal of Sport and Health Research, 9(1): 129-136.

[13] Elian, S.A., \& Hamaidi, D.A. (2018). The Effect of Using Flipped Classroom Strategy on the Academic Achievement of Fourth Grade Students in Jordan. International Journal of Emerging Technologies in Learning, 13(2): 110-125. DOI:10.3991/ijet.v13i02.7816 https://doi.org/10.3991/ijet.v13i02.7816 
[14] Miragall, M., \& García-Soriano, G. (2016). Transforming a class from the Psychology degree into a flipped classroom. @tic. Revista d'innovació educativa, 17: 21-29. DOI:10.7203/attic.17.9097 https://doi.org/10.7203/attic.17.9097

[15] González, D., Jeong, J.S., Cañada, F., \& Gallego, A. (2017). Teaching science contents through a «Flipped» model: An instruction example for Primary Education bachelor students. Enseñanza de las Ciencias, 35(2): 71-87.

https://doi.org/10.5565/rev/ensciencias. 2233

[16] Barao, L., \& Palau, R.F. (2016). Review of the implementation of flipped classroom in the core subjects of 4 year in ESO (obligatory secondary education). EDUTEC. Revista Electrónica de Tecnología Educativa, 55: 1-13. https://doi.org/10.21556/edutec.2016.55.733

[17] Kanelopoulos, J., Papanikolaou, K.A., \& Zalimidis, P. (2017). Flipping The Classroom to Increase Students' Engagement and Interaction in a Mechanical Engineering Course on Machine Design. International Journal of Engineering Pedagogy, 7(4), 19-34. DOI:10.3991/ijep.v7i4.7427 https://doi.org/10.3991/ijep.v7i4.7427

[18] Hernández, R., Fernández, C., \& Baptista, P. (2016). Metodología de la investigación ( $6^{a}$ edición). México: McGraw-Hill - Interamericana de México.

\section{$7 \quad$ Authors}

Francisco-Javier Hinojo-Lucena, University of Granada, Spain, has 276 citations to his credit with 61 research items. E-Mail fhinojo@ugr.es

Inmaculada Aznar-Díaz, University of Granada, Spain

María-Pilar Cáceres-Reche, University of Granada, Spain

José-María Romero-Rodríguez, University of Granada, Spain

Article submitted 2018-11-13. Resubmitted 2018-12-15. Final acceptance 2018-12-15. Final version published as submitted by the authors. 